OPEN ACCESS

Edited by:

Maximo Vento,

University and Polytechnic Hospital of

$\mathrm{La} F$, Spain

Reviewed by:

Berndt Urlesberger,

Medical University of Graz, Austria

Pilar Saenz Gonzalez,

University and Polytechnic Hospital of

La Fe, Spain

*Correspondence:

Baukje M. Dotinga

b.m.dotinga@umcg.nl

Specialty section:

This article was submitted to

Neonatology,

a section of the journa

Frontiers in Pediatrics

Received: 07 April 2020

Accepted: 28 May 2020

Published: 03 July 2020

Citation:

Dotinga BM, Mintzer JP, Moore JE, Hulscher JBF, Bos AF and Kooi EMW

(2020) Maturation of Intestinal

Oxygenation: A Review of

Mechanisms and Clinical Implications

for Preterm Neonates.

Front. Pediatr. 8:354.

doi: 10.3389/fped.2020.00354

\section{Maturation of Intestinal Oxygenation: A Review of Mechanisms and Clinical Implications for Preterm Neonates}

\author{
Baukje M. Dotinga ${ }^{1 *}$, Jonathan P. Mintzer ${ }^{2}$, James E. Moore ${ }^{3}$, Jan B. F. Hulscher ${ }^{4}$, \\ Arend F. Bos ${ }^{1}$ and Elisabeth M. W. Kooi ${ }^{1}$ \\ 1 Division of Neonatology, Department of Pediatrics, Beatrix Children's Hospital, University Medical Center Groningen, \\ University of Groningen, Groningen, Netherlands, ${ }^{2}$ Division of Neonatal-Perinatal Medicine, Department of Pediatrics, \\ Mountainside Medical Center, Montclair, NJ, United States, ${ }^{3}$ Division of Neonatal-Perinatal Medicine, Department of \\ Pediatrics, Connecticut Children's Medical Center, University of Connecticut School of Medicine, Hartford, CT, United States, \\ ${ }^{4}$ Division of Pediatric Surgery, Department of Surgery, University Medical Center Groningen, Groningen, Netherlands
}

Nutrient requirements of preterm neonates may be substantial, to support growth and maturation processes in the presence of challenging post-natal circumstances. This may be accompanied by substantial intestinal oxygen requirements. Preterm neonates may not be able to meet these oxygen requirements, due to a developmental delay in intestinal oxygenation regulation mechanisms. This review summarizes the available literature on post-natal maturation of intestinal oxygenation mechanisms and translates these changes into clinical observations and potential implications for preterm neonates. The different mechanisms that may be involved in regulation of intestinal oxygenation, regardless of post-natal age, are first discussed. The contribution of these mechanisms to intestinal oxygenation regulation is then evaluated in newborn and mature intestine. Finally, the course of clinical observations is used to translate these findings to potential implications for preterm neonates.

Keywords: newborn, preterm neonates, intestinal circulation, intestinal oxygenation, near-infrared spectroscopy, growth and development

\section{INTRODUCTION}

The major functions of the intestine are immunological and digestion-absorption $(1,2)$. The immunological function includes a wide variety of cells and strategies, beyond the scope of this review, and among other things prevents bacterial translocation across the epithelium in the presence of microbial colonization of the gut $(1,3,4)$. The digestive-absorptive function includes production of digestive enzymes and absorption of carbohydrates, lipids, proteins, and vitamins (2). Ultimately, the intestine provides required nutrients to support body growth and function. The nutrient requirements of neonates may be substantial, consequent to maturation processes and tissue growth $(5,6)$. In preterm neonates, these nutritional requirements may be even greater, due to challenging post-natal circumstances, e.g., infection and respiratory distress (7). To meet ongoing nutritional demands, sufficient intestinal oxygenation is essential for intestinal function (8).

After birth, the intestine transitions from a relatively dormant organ to the sole site for nutrient absorption, thus requiring a concomitant increase in oxygen supply (9). This transition is accompanied by rapid tissue growth relative to the whole body, as the intestine increases its weight by $40-70 \%$ within $24 \mathrm{~h}$ and 4 -fold within 10 days (10). Additionally, the change from continuously swallowing amniotic fluid to tolerating intermittent enteral feeds may alter intestinal physiology 
(11). Therefore, the intestine and its associated circulation are subject to a considerable fetal-to-neonatal adaptation which continues to mature during early life $(9,11)$. Although little is known about post-natal changes in the intestinal circulation of preterm neonates, it can be speculated that these occur with increasing gestational age and post-natal age, as was recently described for the cerebral circulation (12). Among other factors, this may predispose preterm neonates to gastrointestinal complications, such as feeding issues, necrotizing enterocolitis (NEC), and poor growth (13-15).

Monitoring of intestinal oxygenation may facilitate early identification of gastrointestinal complications. Intestinal blood flow velocity can be measured using Doppler, but this provides only momentary information on oxygen delivery and not oxygen consumption (16). Near-infrared spectroscopy (NIRS) is a non-invasive, bedside technique used to continuously monitor regional oxygen saturation $\left(\mathrm{rSO}_{2}\right)$ (17). Previous studies have reported promising results for splanchnic $\mathrm{rSO}_{2}\left(\mathrm{r}_{\mathrm{s}} \mathrm{SO}_{2}\right)$ monitoring for detecting hemodynamic changes that accompany physiologic and pathophysiologic conditions $(18,19)$. Currently, the use of splanchnic NIRS remains mostly limited to research settings. A better understanding of the different mechanisms regulating intestinal oxygenation may facilitate interpretation of $\mathrm{r}_{\mathrm{s}} \mathrm{SO}_{2}$ and advance clinical applications of $\mathrm{r}_{\mathrm{s}} \mathrm{SO}_{2}$-monitoring.

In this review, we will first discuss the presumed mechanisms regulating intestinal oxygenation regardless of post-natal age, derived primarily from animal models. Next, we will discuss maturation of these mechanisms and elaborate on potential clinical implications for preterm neonates.

\section{OVERVIEW OF MECHANISMS REGULATING INTESTINAL OXYGENATION}

Intestinal oxygenation represents the balance between oxygen supply and oxygen demand. Intestinal oxygen supply can be divided into convective delivery, from mesenteric arteries to intestinal capillaries, and diffusive delivery, from intestinal capillaries to parenchymal cells (20). Convective delivery depends on intestinal blood flow and arterial oxygen content and is modulated by resistance vessels, i.e., terminal mesenteric and submucosal arterioles $(20,21)$. In contrast, diffusive delivery depends on functional capillary density and capillary-to-cell local $\mathrm{PO}_{2}$ gradients, and is modulated by precapillary sphincters $(20$, 21).

Intestinal oxygenation is regulated at both local and systemic levels $(21,22)$. Local mechanisms provide real-time modulation of intestinal oxygenation and reflect an intestinal intrinsic capacity $(21,23)$. Systemic, or extrinsic, mechanisms integrate intestinal circulation into the systemic circulation (22). In the next sections, we will discuss these mechanisms in more detail. These mechanisms are summarized in Figure 1.

\section{Intrinsic Regulation of Intestinal Oxygenation}

Intrinsic mechanisms for regulating intestinal oxygenation are divided into myogenic factors, metabolic factors, and endothelial vasoactive compounds (24). Both myogenic and metabolic factors participate in pressure-flow autoregulation, i.e., the ability to maintain vascular flow during changes in perfusion pressure. However, the contribution of metabolic factors to this phenomenon seem to exceed those of myogenic factors (25). Additionally, overall vascular responses may be modified by endothelial vasoactive compounds (26).

The myogenic mechanism aims to sustain capillary pressure and transcapillary fluid exchange during changes in transmural pressure $(23,27)$. Increases in intravascular pressure lead to vasoconstriction in resistance vessels and closure of precapillary sphincters (28). Myogenic vasoconstriction in response to circumferential stretch of vascular smooth muscle is mediated by $\mathrm{Ca}^{2+}$ influx, $\mathrm{Ca}^{2+}$ release from the sarcoplasmic reticulum, and increased $\mathrm{Ca}^{2+}$-sensitivity of contractile myofilaments (29). Intracellular signaling pathways leading to these events may involve protein kinase C (30).

The metabolic mechanism aims to sustain blood flow and oxygen delivery during changes in tissue metabolism (23). Increases in tissue metabolism leads to vasodilation of resistance vessels and relaxation of precapillary sphincters, by reduction of tissue $\mathrm{PO}_{2}$ and interstitial accumulation of vasoactive metabolites, such as $\mathrm{H}^{+}, \mathrm{K}^{+}$, and adenosine (23). Moderate increases in tissue metabolism seem to be associated with augmented diffusive oxygen delivery, whereas greater increases in tissue metabolism seem to be supported by augmentation of convective oxygen delivery (31).

Endothelial vasoactive compounds modulate vascular resistance during changes in shear stress generated by blood flow against the static endothelium (26). The principal relaxing factor is nitric oxide (NO) (32-34). The principal constricting factor is endothelin-1 (ET-1) (35). Although activation of both $\mathrm{ET}_{\mathrm{A}}$ - and $\mathrm{ET}_{\mathrm{B}}$-receptors on smooth muscle cells leads to vasoconstriction, activation of $\mathrm{ET}_{\mathrm{B}}$-receptors on endothelial cells leads to NO-mediated vasodilation (35).

It has been suggested that the enteric nervous system participates in regulation of intestinal oxygenation, however, as this seems to be mediated via endothelial release of nitric oxide (NO), this will not be discussed separately (36). A direct effect of gastrointestinal hormones and peptides in the regulation of intestinal oxygenation has not been clearly established and will therefore not be further addressed in this review (23).

\section{Extrinsic Regulation of Intestinal Oxygenation}

Extrinsic mechanisms include neural factors and circulating vasoactive compounds (22). The physiological role of these compounds, including norepinephrine, angiotensin II, vasopressin, histamine, and bradykinin, is uncertain, as these were mostly studied using exogenous administration (23).

Splanchnic nerve stimulation produces a pattern of changes in the intestinal vasculature that is characterized by three phases: a constrictor phase, an escape phase, and a hyperemic phase (23). First, nerve stimulation leads to constriction of resistance vessels and closure of precapillary sphincters. However, during continued sympathetic stimulation, blood flow 


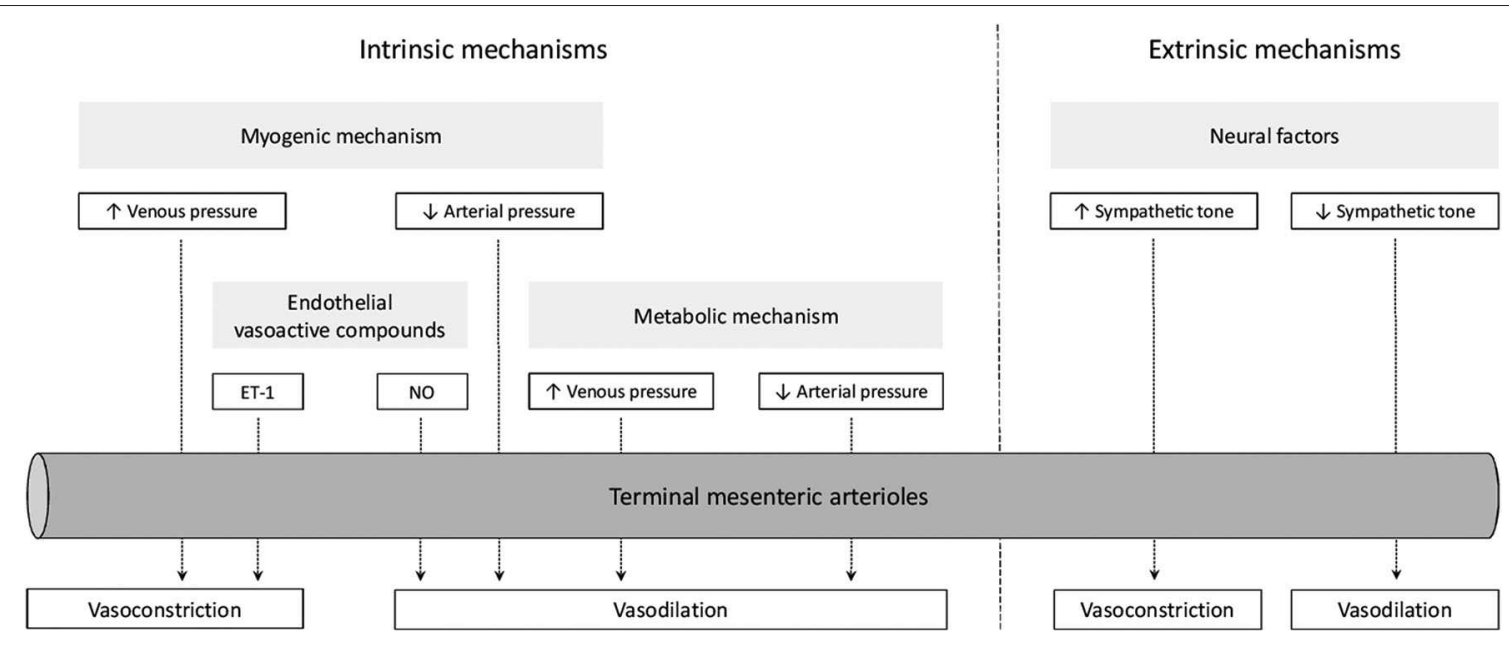

FIGURE 1 | Overview of mechanisms regulating intestinal oxygenation. ET-1, endothelin-1; NO, nitric oxide.

partially recovers. It is suggested that accumulation of local metabolites and/or release of vasodilators from sensory nerves causes this autoregulatory escape by relaxation of previously constricted resistance vessels (37). Cessation of sympathetic stimulation is followed by a hyperemic phase before blood flow gradually returns to baseline (38). This post-stimulatory hyperemia may be explained by vasodilator metabolite release during the escape phase (39).

The intestine is extensively innervated by parasympathetic fibers originating from the vagus nerve. Although these fibers may have an indirect effect on intestinal oxygenation via changes in intestinal motility and secretion, there does not appear to be a direct vasoactive effect (23).

Several reviews on post-natal maturation of these intrinsic and extrinsic mechanisms describe that some may not be functionally mature at birth, whereas others may functionally decline in the post-natal period $(9,40-44)$. However, these reviews do not provide guidance for clinical practice, specifically with regard to preterm neonates. Therefore, our aim was to review the literature on maturation of intestinal oxygenation mechanisms and translate these changes into clinical observations with potential implications for preterm neonates.

\section{METHODS}

A literature search was conducted to evaluate reports on the post-natal maturation of intestinal oxygenation mechanisms in neonates. The search strategy is presented in Table 1. English-language articles were selected only if they included a comparison between newborn and mature intestinal oxygenation. Furthermore, as we were mostly interested in baseline intestinal hemodynamics, we excluded articles in which external influences or interventions were investigated. In addition to the database search, we screened the reference lists of all relevant articles for additional publications. To identify clinical studies in preterm neonates, the search strategy was repeated, following the same stepwise procedure, with several additional search terms, as presented in Table 1. We excluded articles that included only sick infants or studied the effect of external influences. In case a control group was included, we included the article, but only present results for the control group.

\section{RESULTS}

Our initial search resulted in 9,837 articles. We assessed titles and abstracts of all articles, of which 114 appeared relevant. One additional publication was ascertained using the reference lists within these articles. After reading the full texts, 27 articles were included in this review (Figure 2A). The main findings are presented in Table 2.

\section{Postnatal Maturation of Mechanisms Regulating Intestinal Oxygenation}

In the neonatal intestine, basal vascular resistance seems to be determined by myogenic factors, endothelial vasoactive compounds, and neural factors, based on observations in newborn swine $(45,51,55,58,61,66,67)$. Using a swine model, Nowicki et al. (46) demonstrated in several studies that pressure-flow autoregulation is absent in neonatal intestine (54). Therefore, decreases in arterial pressure result in decreased intestinal blood flow. Moreover, these studies indicate that subsequent increases in oxygen extraction are insufficient to meet intestinal oxygen demand $(48,50,53)$. The absence of pressure-flow autoregulation may indicate immaturity of the myogenic and/or metabolic mechanisms described above. However, myogenic vasoconstriction has been observed in newborn swine in response to increases in venous pressure $(45,47,54,58,62)$. Therefore, it seems more likely that the absence of pressure-flow autoregulation reflects immaturity of the metabolic mechanism. Neonatal intestine may thus lack an important vasodilator mechanism. 
TABLE 1 | Search strategy.

\begin{tabular}{|c|c|c|}
\hline$\#$ & Searches & Results \\
\hline \multicolumn{3}{|c|}{ Postnatal maturation of intestinal oxygenation mechanisms } \\
\hline 1 & Intestine, small [mh] & 160,222 \\
\hline 2 & Splanchnic circulation/physiology [mh] & 2,523 \\
\hline 3 & Intestine, small/blood supply ${ }^{*}[\mathrm{mh}]$ & 6,624 \\
\hline 4 & Intestine, small/physiology [mh] & 52,907 \\
\hline 5 & Mesenteric arteries [mh] & 16,536 \\
\hline 6 & Splanchnic [tiab] & 9,642 \\
\hline 7 & Abdom* [tiab] & 344,335 \\
\hline 8 & Intestin* [tiab] & 361,977 \\
\hline 9 & Mesenter $[$ tiab] & 59,868 \\
\hline 10 & $\begin{array}{l}\text { \#1 OR \#2 OR \#3 OR \#4 OR \#5 OR \#6 OR \#7 } \\
\text { OR \#8 OR \#9 }\end{array}$ & 815,899 \\
\hline 11 & Hemodynamics/physiology [mh] & 153,990 \\
\hline 12 & Vascular resistance/physiology [mh] & 7,376 \\
\hline 13 & Vasoconstriction/physiology [mh] & 6,745 \\
\hline 14 & Vasodilation/physiology [mh] & 10,143 \\
\hline 15 & Hemodynamics [tiab] & 48,463 \\
\hline 16 & Vascular resistance [tiab] & 31,064 \\
\hline 17 & Vasoconstrict* [tiab] & 42,933 \\
\hline 18 & Vasodilat $^{\star}[$ tiab] & 67,236 \\
\hline 19 & Perfusion [tiab] & 159,441 \\
\hline 20 & Circulat $^{\star}[$ tiab] & 403,596 \\
\hline 21 & Blood flow [tiab] & 167,197 \\
\hline 22 & Oxygenation [tiab] & 51,192 \\
\hline 23 & $\begin{array}{l}\# 11 \text { OR \#12 OR \#13 OR \#14 OR \#15 OR \#16 } \\
\text { OR \#17 OR \#18 OR \#19 OR \#20 OR \#21 OR } \\
\text { \#22 }\end{array}$ & 924,027 \\
\hline 24 & \#10 AND \#23 & 49,658 \\
\hline 25 & Infant, Newborn [mh] & 600,550 \\
\hline 26 & Infant [tiab] & 216,859 \\
\hline 27 & Newborn [tiab] & 137,450 \\
\hline 28 & Neonat $^{\star}[$ tiab] & 263,693 \\
\hline 29 & Post-natal [tiab] & 103,008 \\
\hline 30 & Develop* [tiab] & $4,280,256$ \\
\hline 31 & \#25 OR \#26 OR \#27 OR \#28 OR \#29 OR \#30 & $5,003,395$ \\
\hline 32 & \#24 AND \#31 & 9,837 \\
\hline \multicolumn{3}{|c|}{ Clinical observations } \\
\hline 33 & Ultrasonography [mh] & 70,985 \\
\hline 34 & Doppler [tiab] & 102,865 \\
\hline 35 & Spectroscopy, Near-Infrared [mh] & 13,026 \\
\hline 36 & Near-infrared spectroscopy [tiab] & 11,392 \\
\hline 37 & \#33 OR \#34 OR \#35 OR \#36 & 490,849 \\
\hline 38 & \#32 AND \#37 & 330 \\
\hline 39 & Preterm [tiab] & 67,490 \\
\hline 40 & \#38 AND \#39 & 145 \\
\hline
\end{tabular}

\#, search number; ${ }^{*}$, truncation; $\mathrm{mh}, \mathrm{MeSH}$ term; tiab, title or abstract

Moreover, there may be a greater amount of constricting factors, as demonstrated by a greater quantity of $\mathrm{ET}_{\mathrm{A}}$ - and $\mathrm{ET}_{\mathrm{B}^{-}}$ receptors in newborn swine compared to mature swine $(59,63)$. In the presence of these vasoconstrictor influences, i.e., the myogenic mechanism and ET-1, there seems to be an important role for $\mathrm{NO}$ as a vasodilator to maintain intestinal oxygenation in neonates. This assumption is supported by findings of Reber et al. $(60,61)$ who demonstrated that NO production is considerably greater in newborn swine compared with mature swine under both basal and stimulated conditions.

In mature intestine, basal vascular resistance seems to be determined by passive-elastic characteristics of the vasculature rather than active constrictor or dilator tone, based on observations in mature swine $(42,46,53)$. Pressure-flow autoregulation is present in mature swine and seems to be associated with venous $\mathrm{PO}_{2}$, consistent with the metabolic mechanism described above $(46,48-50,53,54)$. Therefore, during decreases in arterial pressure, blood flow is still maintained in mature swine compared to newborn swine and concomitant increases in oxygen extraction may enable mature intestine to more consistently meet oxygen demand $(46,48-50$, $53,54)$. In contrast to newborn swine, myogenic vasoconstriction in response to venous pressure elevation seems to be absent in mature swine $(47,54,58,62)$. As the influence of vasoconstrictor forces, i.e., the myogenic mechanism and ET-1, decreases with advancing post-natal age, it follows that mature intestine may not require the same vasodilator forces as neonatal intestine. Indeed, several studies showed that NO production and the degree of flow-induced vasodilation are considerably smaller in mature swine than in newborn swine $(51,54,60,61)$.

In conclusion, during post-natal maturation, the contribution of the metabolic mechanism in regulation of intestinal oxygenation increases, whereas the influences of the myogenic mechanism and endothelial vasoactive compounds decrease. In neonatal intestine, pressure-flow autoregulation is not yet functional, possibly due to immaturity of the metabolic mechanism.

\section{Translation to Clinical Observations}

To the best of our knowledge, there are no studies available that investigate post-natal maturation of intestinal oxygenation mechanisms in preterm intestine, nor studies that compared maturation of intestinal oxygenation mechanisms between preterm and term intestine.

Therefore, we used the clinical studies that were identified by the additional search strategy to translate the results into clinical observations for preterm neonates. Our additional search resulted in 145 articles. We assessed titles and abstracts of all articles, of which 29 appeared relevant. Three additional publication were ascertained using the reference lists within these articles. After reading the full texts, 18 articles were included in this review (Figure 2B). The main findings are presented in Table 3.

In preterm neonates, intestinal perfusion increases in early life, as demonstrated by increases in peak systolic flow (PSV) and time-averaged mean velocity (TAMV), measured with Doppler, until day 28 of life $(73-79,81)$. Despite increases in blood flow during the first weeks of life, splanchnic oxygen saturation $\left(\mathrm{r}_{\mathrm{s}} \mathrm{SO}_{2}\right)$, estimated using near-infrared spectroscopy (NIRS), initially decreases in the first week of life and then increases until day 21 after birth $(83,84,86-88)$. Advancing gestational age 


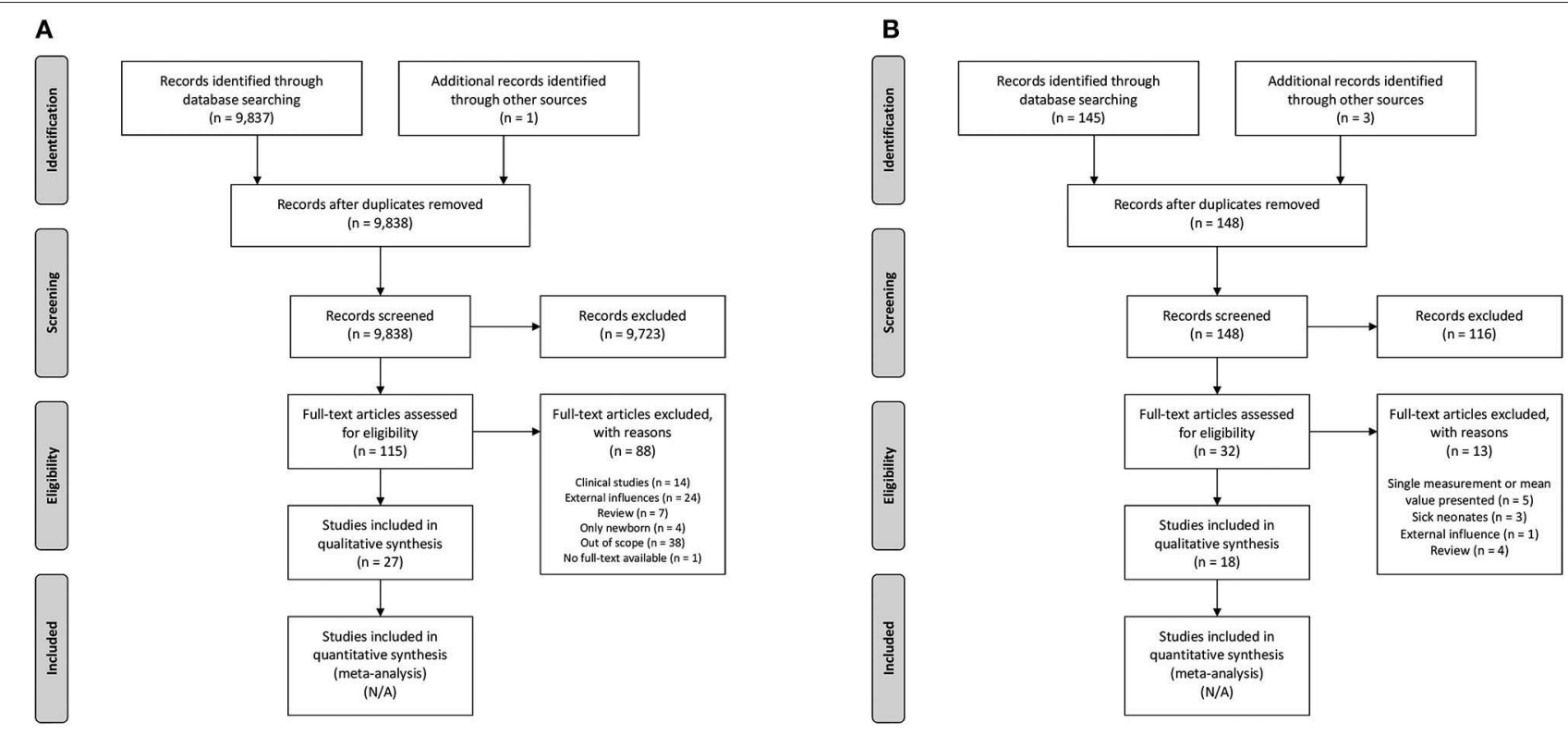

FIGURE 2 | Search strategy. (A) Postnatal maturation of intestinal oxygenation mechanisms, (B) Clinical observations. N/A, not applicable.

(GA) is associated with both higher blood flow and higher $\mathrm{r}_{\mathrm{s}} \mathrm{SO}_{2}$ $(78,80,84)$.

\section{INTERPRETATION AND DISCUSSION}

Our review of the literature shows that pressure-flow autoregulation is only present in mature intestine, as demonstrated in animal studies. In contrast, neonatal intestine relies on increases in oxygen extraction to meet oxygen demand during decreases in arterial pressure. Clinical observations demonstrate lower baseline hemodynamic and oxygenation characteristics in preterm compared to term neonates. These results suggest a developmental delay of vasodilator forces and a smaller reserve to increase intestinal oxygen extraction in preterm neonates that may endanger intestinal oxygenation during decreases in arterial pressure.

Oxygen requirements of neonatal intestine, and specifically those of preterm neonatal intestine, may be substantial, due to a high nutritional demand to support growth and maturation processes (7). Our review of the literature shows that preterm neonates may not be able to meet these requirements, as pressureflow autoregulation is still absent and increases in oxygen extraction are insufficient to meet tissue oxygen demand $(46,48-$ $50,53,54)$. Clinical studies showed that $\mathrm{r}_{\mathrm{s}} \mathrm{SO}_{2}$ initially decreases after birth, possibly indicating that oxygen extraction is already maximized under basal conditions $(83,84,86,87)$. Although the course of intestinal blood flow and $\mathrm{r}_{\mathrm{s}} \mathrm{SO}_{2}$ in early postnatal life has not been studied with simultaneous Doppler and NIRS measurements, the initial decrease in $\mathrm{r}_{\mathrm{s}} \mathrm{SO}_{2}$ suggests that the increase in oxygen extraction is greater than the increase in blood flow during the first days of life. We hypothesize that this could be due to patency of the ductus arteriosus. This hypothesis is supported by findings of Ledo et al. (87) who investigated the effect of ductal patency on the course of $\mathrm{r}_{\mathrm{s}} \mathrm{SO}_{2}$ in preterm neonates and found that the increases in $\mathrm{r}_{\mathrm{s}} \mathrm{SO}_{2}$ from day 3 of life are paralleled by ductal closure. The initial decrease in $\mathrm{r}_{\mathrm{s}} \mathrm{SO}_{2}$ may thus be explained by ductal steal, resulting in reduced diastolic flow in the descending aorta, resulting in a decreased intestinal perfusion pressure, and in the absence of intestinal pressure-flow regulation, preterm intestine relies on increases in oxygen extraction $(73,74,80,82,87)$. This may enable preterm neonates to meet intestinal oxygen requirements during baseline conditions, yet creates unfavorable conditions during periods of additional stress. A recent review by Chaaban et al. (44) showed that the predominant response of neonatal intestine to decreases in oxygen delivery or increases in oxygen demand is increased oxygen extraction. In preterm neonates, however, it may not be possible to further increase oxygen extraction. Therefore, during periods of additional oxygen requirements, preterm neonates may fail to meet intestinal oxygen requirements, leading to disruption of the intestinal barrier and reduced nutrient absorption.

There may be an important role for NO to facilitate oxygen delivery in neonatal intestine during baseline conditions. Our review of the literature demonstrates that NO counteracts active vasoconstrictor tone, induced by myogenic factors and ET1. Clinical studies showed that intestinal blood flow increases with advancing post-natal age, possibly indicating maturation of vasodilator forces. Although no causal relation between intestinal blood flow and NO production has been demonstrated, Reber et al. $(60,61)$ found that the post-natal increase in intestinal blood flow is paralleled by increases in NO production in neonatal swine. Reber et al. (9) hypothesized that loss of NO production may compromise intestinal oxygen delivery and thus contribute to intestinal injury in neonates. This hypothesis is supported by findings of Nowicki et al. (89) who showed that NO-mediated vasodilation was disrupted in human intestine resected for NEC. The pathophysiology of NEC is complex 
TABLE 2 | Postnatal maturation of intestinal oxygenation mechanisms.

\begin{tabular}{|c|c|c|c|c|c|c|c|}
\hline Year & Author & Species & $n$ & Ages & Newborn & Adolescent/adult & Comparison \\
\hline
\end{tabular}

\section{Intrinsic mechanisms}

$1988 \quad$ Crissinger

et al. (45)

Swine

$1,3 \mathrm{~d}, 2$
wk, $1 \mathrm{mo}$

Venous pressure elevations led to

reductions in blood flow and

increases in $(\mathrm{a}-\mathrm{v}) \mathrm{O}_{2}$. Oxygen uptake

increased in animals aged 1 day and

remained unchanged in animals aged

3 days. Total vascular resistance

decreased in response to venous

pressure elevation in animals aged 1

day and increased in animals aged 3

days.

$\begin{array}{llll}\text { Nowicki et al. Swine } & 18 & 3,35 d \\ \text { (46) }\end{array}$

1990

Nowicki et al.

Swine

(47)
Blood flow decreased in response to reductions in perfusion pressure. Oxygen uptake increased in response to reductions in perfusion pressure.

Pressure-flow autoregulation was absent.

During free flow, blood flow decreased and $(a-v) \mathrm{O}_{2}$ initially

remained unchanged in response to venous pressure elevation, therefore oxygen uptake decreased. Greater venous pressure elevation led to increased $(\mathrm{a}-\mathrm{v}) \mathrm{O}_{2}$ and maintained oxygen uptake.

Oxygen uptake decreased in response to arterial pressure reduction. Pressure-flow autoregulation was absent.

Increased oxygen demand led to greater oxygen uptake resulting from increased $(a-v) \mathrm{O}_{2}$. Pressure-flow autoregulation was absent.

Pressure-flow autoregulation was absent. The $(a-v) \mathrm{O}_{2}$ increased in response to perfusion pressure reductions, but the magnitude of the increase diminished with lower pressures. Oxygen uptake decreased significantly in response to perfusion pressure reductions.
Venous pressure elevation led to decreased blood flow, increased $(a-v) \mathrm{O}_{2}$ and decreased oxygen uptake. Total vascular resistance increased in response to venous pressure elevations.

Blood flow decreased in response to reductions in perfusion pressure. Oxygen uptake increased in response to reductions in perfusion pressure. Pressure-flow autoregulation was present.

During free flow, blood flow decreased and $(\mathrm{a}-\mathrm{v}) \mathrm{O}_{2}$ remained unchanged in response to venous pressure elevation, therefore oxygen uptake decreased.

Oxygen uptake was maintained during arterial pressure reduction. Pressure-flow autoregulation was present and associated with venous $\mathrm{PO}_{2}$, but not with blood flow.

Increased oxygen demand led to greater oxygen uptake resulting from increased $(a-v) \mathrm{O}_{2}$. Pressure-flow autoregulation was present.

Pressure-flow autoregulation was present. The $(a-v) \mathrm{O}_{2}$ increased in response to perfusion pressure reductions. Oxygen uptake only decreased in response to the greatest reduction in perfusion pressure
Venous pressure elevation led to greater reductions in blood flow and oxygen uptake in all older animals compared to animals at day 1 .

Predominance of metabolic factors at day 1 and myogenic factors in older animals is suggested as evidenced by the total vascular resistance.

Pressure-flow autoregulation was only present in older animals. Blood flow decreased and oxygen uptake

increased to a similar extent in both age groups. As a consequence, oxygen uptake was more effectively maintained in older animals.

In response to venous pressure elevation, blood flow and oxygen

uptake decreases to a greater extent in newborn animals.

Pressure-flow autoregulation was only present in older animals. Oxygen uptake was only maintained in older animals.

Pressure-flow autoregulation was only present in older animals.

Pressure-flow autoregulation was only present in older animals. Oxygen uptake was only maintained in older animals. 
TABLE 2 | Continued

\begin{tabular}{|c|c|c|c|c|c|c|c|}
\hline Year & Author & Species & $n$ & Ages & Newborn & Adolescent/adult & Comparison \\
\hline 1995 & $\begin{array}{l}\text { Nankervis } \\
\text { et al. (51) }\end{array}$ & Swine & 10 & $3,35 d$ & $\begin{array}{l}\text { Inhibited } \mathrm{NO} \text { production increased } \\
\text { vascular resistance and }(\mathrm{a}-\mathrm{v}) \mathrm{O}_{2} \text {, no } \\
\text { changes in oxygen uptake were } \\
\text { observed. Vasodilation was observed } \\
\text { in response to increased flow. } \\
\text { Inhibited NO production increased } \\
\text { vascular resistance during increased } \\
\text { flow rates. }\end{array}$ & $\begin{array}{l}\text { Inhibited NO production did not affect } \\
\text { vascular resistance, nor oxygen } \\
\text { uptake. Vasodilation was observed in } \\
\text { response to increased flow. Inhibited } \\
\text { NO production did not have an effect } \\
\text { on vascular resistance during } \\
\text { increased flow. }\end{array}$ & $\begin{array}{l}\text { Only in newborn animals, the } \\
\text { NO-cGMP axis participates in setting } \\
\text { basal vascular resistance and in } \\
\text { flow-induced dilation. Flow-induced } \\
\text { dilation was present in both age } \\
\text { groups. }\end{array}$ \\
\hline 1997 & $\begin{array}{l}\text { Nakanishi } \\
\text { et al. (52) }\end{array}$ & Rabbits & 36 & $\begin{array}{l}3-5 \mathrm{~d} \\
4-8 \mathrm{mo}\end{array}$ & $\begin{array}{l}\text { Inhibited } \mathrm{Ca}^{2+} \text {-influx caused } \\
\text { vasorelaxation. Stimulated } \\
\mathrm{Ca}^{2+} \text {-release from intracellular store } \\
\text { sites caused vasoconstriction. }\end{array}$ & $\begin{array}{l}\text { Inhibited } \mathrm{Ca}^{2+} \text {-influx caused } \\
\text { vasorelaxation. Stimulated } \\
\mathrm{Ca}^{2+} \text {-release from intracellular store } \\
\text { sites caused vasoconstriction. }\end{array}$ & $\begin{array}{l}\text { Newborn animals showed greater } \\
\text { vasoconstriction in response to } \\
\text { stimulated } \mathrm{Ca}^{2+} \text {-release from } \\
\text { intracellular stores, whereas older } \\
\text { animals showed greater } \\
\text { vasorelaxation in response to inhibited } \\
\mathrm{Ca}^{2+} \text {-influx through } \mathrm{Ca}^{2+} \text {-channels } \\
\text { across the sarcolemma. }\end{array}$ \\
\hline 1998 & Nowicki (53) & Swine & 14 & $3,35 d$ & $\begin{array}{l}\text { Blood flow decreased, }(a-v) \mathrm{O}_{2} \\
\text { increased and oxygen uptake } \\
\text { decreased in response to reduced } \\
\text { flow, achieved by perfusion pressure } \\
\text { reductions. Vascular resistance } \\
\text { increased in response to perfusion } \\
\text { pressure reductions. }\end{array}$ & $\begin{array}{l}\text { Blood flow decreased, }(\mathrm{a}-\mathrm{v}) \mathrm{O}_{2} \\
\text { increased and oxygen uptake } \\
\text { remained unchanged in response to } \\
\text { reduced flow, achieved by perfusion } \\
\text { pressure reductions. Vascular } \\
\text { resistance increased in response to } \\
\text { perfusion pressure reductions. }\end{array}$ & $\begin{array}{l}\text { In newborn animals, vascular } \\
\text { resistance increases to a greater } \\
\text { extent in response to perfusion } \\
\text { pressure reductions. Oxygen uptake } \\
\text { is only maintained in older animals } \\
\text { during perfusion pressure reductions. }\end{array}$ \\
\hline 1998 & $\begin{array}{l}\text { Reber et al. } \\
(54)\end{array}$ & Swine & 14 & $3,35 d$ & $\begin{array}{l}\text { Myogenic vasoconstriction in } \\
\text { response to increased intravascular } \\
\text { pressure was present. Flow-mediated } \\
\text { dilation was present. Vasodilation was } \\
\text { noted in response to combined } \\
\text { increases in pressure and flow. } \\
\text { Pressure-flow autoregulation was } \\
\text { absent. }\end{array}$ & $\begin{array}{l}\text { Myogenic vasoconstriction in } \\
\text { response to increased intravascular } \\
\text { pressure was absent. Flow-mediated } \\
\text { dilation in response to increased flow } \\
\text { was present. A modest degree of } \\
\text { pressure-flow autoregulation was } \\
\text { observed. }\end{array}$ & $\begin{array}{l}\text { Myogenic vasoconstriction was only } \\
\text { observed in newborn animals. A } \\
\text { greater degree of flow-induced } \\
\text { dilation was observed in newborn } \\
\text { animals. Vasodilation in response to } \\
\text { combined increases in pressure and } \\
\text { flow was only observed in newborn } \\
\text { animals. Pressure-flow autoregulation } \\
\text { was only present in older animals. }\end{array}$ \\
\hline 1999 & Nowicki (55) & Swine & 50 & $3,35 d$ & $\begin{array}{l}\text { Vasoconstriction was observed in } \\
\text { response to reduction of flow rate. } \\
\text { Inhibited NO production increased } \\
\text { vascular resistance. Low flow } \\
\text { conditions caused increased } \\
\text { vasoconstriction in response to ET-1 } \\
\text { and these effect were even greater } \\
\text { during inhibited NO production. }\end{array}$ & $\begin{array}{l}\text { Vasoconstriction was observed in } \\
\text { response to reduction of flow rate. } \\
\text { Inhibited NO production increased } \\
\text { vascular resistance. Low flow } \\
\text { conditions did not alter the response } \\
\text { to ET-1. }\end{array}$ & $\begin{array}{l}\text { In newborn animals, low flow } \\
\text { conditions caused greater } \\
\text { vasoconstriction and a greater } \\
\text { vasoconstrictor response to ET-1. } \\
\text { Inhibited NO production increased } \\
\text { vascular resistance to a greater extent } \\
\text { in newborn animals. }\end{array}$ \\
\hline
\end{tabular}


TABLE 2 | Continued

\begin{tabular}{lllll}
\hline Year & Author & Species & $\boldsymbol{n}$ & Ages \\
\hline 2000 & $\begin{array}{l}\text { Nankervis } \\
\text { et al. (56) }\end{array}$ & Swine & 10 & $3,35 \mathrm{~d}$
\end{tabular}

Adolescent/adult

Comparison

vasoconstriction and decreased

striction and decrease

$(a-v) O_{2}$. Oxygen uptake was

compromised during ET-1 infusion.

Blockade of $\mathrm{ET}_{\mathrm{A}}$-receptors did no

compromised during ET-1 infusion.

Blockade of $\mathrm{ET}_{\mathrm{A}}$-receptors did not

alter basal vascular tone. Blockade of

$\mathrm{ET}_{\mathrm{B}}$-receptors increased the extent of

ascular tone. Blockade of

ptors had no effect on

$(\mathrm{a}-\mathrm{v}) \mathrm{O}_{2}$.

Blockade of $\mathrm{ET}_{\mathrm{A}}$-receptors did not alter basal vascular resistance, but increased oxygen uptake. Blockade of $E T_{B}$-receptors and removal of the endothelium increased

vasoconstriction in response to ET-1.

Myogenic vasoconstriction was observed in response to increased vascular pressure under no-flow circumstances, whereas vasodilation was observed in the presence of flow. Blockade of $E T_{A}$-receptors caused vasodilation, but only in the absence of flow. Blockade of $\mathrm{ET}_{\mathrm{B}}$-receptors and NO production caused

vasoconstriction regardless of flow conditions.

$2001 \quad$ Nankervis

et al. (59)

Swine

$\begin{aligned} & \text { Reber et al. Swine } \\ & \text { (61) }\end{aligned}$
 $\begin{aligned} & \begin{array}{l}1,3,10, \\ 30 \mathrm{~d}\end{array}\end{aligned}$

$E T_{A}$-receptors were present and

localized to vascular smooth muscle.

$E T_{B}$-receptors were present and

localized to the endothelium.

NO production increases and

vascular resistance decreasing in

response to increases in flow rate.

ncreased NO production was

observed in response to decreases in

flow rate, but vascular resistance

remained unchanged.

Expression of eNOS protein was present. Blockade of NO production

increased vascular resistance. vessel diameter, nor $(a-v) \mathrm{O}_{2}$.

Blockade of $\mathrm{ET}_{\mathrm{A}}$-receptors did not alter basal vascular resistance, no oxygen uptake. Blockade of

$E T_{B}$-receptors and removal of the endothelium did not alter

vasoconstriction in response to ET-1.

Myogenic vasoconstriction in response to increased arterial pressure was absent, instead

vasodilation was observed. Blockade of $E T_{A}$-receptors, $E T_{B}$-receptors and NO production produced no effect on vessel diameter.

$E T_{A}$-receptors were present and localized to vascular smooth muscle.

$\mathrm{ET}_{\mathrm{B}}$-receptors were present and localized to the endothelium.

NO production and vascular resistance remained unaltered in response to both increases and decreases in flow rate.

Expression of eNOS protein was present. Blockade of NO production increased vascular resistance at day 10 , but not at day 30 .
In newborn animals, endogenous

ET-1 participates in exchange vesse regulation, but not in setting basa vascular tone. Vasoconstriction

caused by endogenous ET-1 is offset by vasodilation by activation of

$\mathrm{ET}_{\mathrm{B}}$-receptors, but only in newborn animals. In newborn animals, ET-1 infusion leads to greater increases in $(\mathrm{a}-\mathrm{v}) \mathrm{O}_{2}$.

$\mathrm{ET}_{\mathrm{B}}$-receptors are located on the endothelium and modulate the vasoconstrictor response to ET-1, but only in newborn intestine.

Myogenic vasoconstriction in response to increased arterial pressure was only observed in newborn animals. In newborn animals, ET-1 participates in setting basal vascular tone, independent of the myogenic mechanism, that is offset by activation of $\mathrm{ET}_{\mathrm{B}}$-receptors.

$E T_{A}$ - and $E T_{B}$-receptors are present in a greater quantity in newborn intestine comp intestine.

Basal NO production and stimulated NO production in response to increased flow rate were greater in newborn animals. Only in newborn animals, flow-induced dilation was observed.

Expression of eNOS protein increased until day 10 , but then decreased until day 30 , whereas eNOS mRNA remained stable. Compared to 1-day-old animals, vascular resistance was higher in 30-day-old animals. Oxygen uptake increased until day 3 , but then decreased until day 30 . 
TABLE 2 | Continued

\begin{tabular}{|c|c|c|c|c|c|c|c|}
\hline Year & Author & Species & $n$ & Ages & Newborn & Adolescent/adult & Comparison \\
\hline 2003 & Su et al. (62) & Swine & 40 & $1,10 \mathrm{~d}$ & $\begin{array}{l}\text { Vasoconstriction was observed in } \\
\text { response to increased intravascular } \\
\text { pressure. Blockade of PKC eliminated } \\
\text { this vasoconstrictor response. } \\
\text { Activation of PKC increased the } \\
\text { contractile response. }\end{array}$ & $\begin{array}{l}\text { No change in vessel diameter was } \\
\text { observed in response to increased } \\
\text { intravascular pressure. Neither } \\
\text { blockade of PKC nor activation of } \\
\text { PKC produced any changes in vessel } \\
\text { diameter. }\end{array}$ & $\begin{array}{l}\text { The intensity of myogenic } \\
\text { vasoconstriction is greater in newborn } \\
\text { animals. Myogenic vasoconstriction } \\
\text { was attenuated by blockade and } \\
\text { activation of PKC, but only in } \\
\text { newborn animals. }\end{array}$ \\
\hline 2004 & Su et al. (63) & Swine & 12 & $\begin{array}{l}3,10,30 \\
d\end{array}$ & $\begin{array}{l}\mathrm{ET}_{\mathrm{A}} \text { - and } \mathrm{ET}_{\mathrm{B}} \text {-receptor mRNA and } \\
\text { protein expression was present. The } \\
\mathrm{ET}_{\mathrm{A}} \text {-receptor was localized to } \\
\text { vascular smooth muscle and the } \\
\mathrm{ET}_{\mathrm{B}} \text {-receptor was localized to the } \\
\text { endothelial layer. }\end{array}$ & $\begin{array}{l}\mathrm{ET}_{\mathrm{A}} \text { - and } \mathrm{ET}_{\mathrm{B}} \text {-receptor mRNA and } \\
\text { protein expression was present. The } \\
\mathrm{ET}_{\mathrm{A}} \text {-receptor was localized to } \\
\text { vascular smooth muscle and the } \\
\mathrm{ET}_{\mathrm{B}} \text {-receptor was localized to the } \\
\text { endothelial layer. }\end{array}$ & $\begin{array}{l}\mathrm{ET}_{\mathrm{A}} \text { - and } \mathrm{ET}_{\mathrm{B}} \text {-receptor mRNA and } \\
\text { protein expression was greater in } \\
\text { newborn animals. Localization of } \\
\mathrm{ET}_{\mathrm{A}} \text { - and } \mathrm{ET}_{\mathrm{B}} \text {-receptors was similar. }\end{array}$ \\
\hline 2005 & $\begin{array}{l}\text { Wendel et al. } \\
\text { (64) }\end{array}$ & Rats & 15 & $\begin{array}{l}0,5,14 \\
21,28 \mathrm{~d} \\
\text { adult }\end{array}$ & $\begin{array}{l}\mathrm{ET}_{\mathrm{B}} \text {-receptors were absent on } \\
\text { smooth muscle cells in the } \\
\text { mesenteric circulation }\end{array}$ & $\begin{array}{l}\text { From day } 14, \mathrm{ET}_{\mathrm{B}} \text {-receptors were } \\
\text { present on smooth muscle cells of } \\
\text { mesenteric arterioles, but not arteries } \\
\text { and veins }\end{array}$ & $\begin{array}{l}E T_{B} \text {-receptors are only present on } \\
\text { smooth muscles cells of mesenteric } \\
\text { arterioles in mature intestine }\end{array}$ \\
\hline 2020 & $\begin{array}{l}\text { Ayuso et al. } \\
(65)\end{array}$ & Swine & 22 & $\begin{array}{l}0,3,8 \\
19 d\end{array}$ & $\begin{array}{l}\text { In LBW animals, eNOS is present at } \\
\text { birth in a moderate degree. In NBW } \\
\text { animals, eNOS expression peaks at } \\
\text { birth. }\end{array}$ & $\begin{array}{l}\text { In both LBW and NBW, animals, } \\
\text { eNOS expression is present in a } \\
\text { moderate degree. }\end{array}$ & $\begin{array}{l}\text { eNOS expression is greater in } \\
\text { newborn animals than in mature } \\
\text { animals, but only in NBW animals. }\end{array}$ \\
\hline \multicolumn{8}{|c|}{ Extrinsic mechanisms } \\
\hline 1985 & $\begin{array}{l}\text { Buckley et al. } \\
\text { (66) }\end{array}$ & Swine & 34 & $\begin{array}{l}1,2-4 \mathrm{~d} \\
1,2 \mathrm{wk} \\
1 \mathrm{mo}\end{array}$ & $\begin{array}{l}\text { An increase in vascular resistance } \\
\text { was observed in response to } \\
\text { inhibition of the baroreceptor reflex, } \\
\text { achieved by occlusion of the carotid } \\
\text { arteries. The circulation is under } \\
\text { neural vasoconstrictor tone, as } \\
\text { evidenced by decreased vascular } \\
\text { resistance in response to section of } \\
\text { the splanchnic nerve. SpNS } \\
\text { produced vasoconstriction. }\end{array}$ & $\begin{array}{l}\text { An increase in vascular resistance } \\
\text { was observed in response to } \\
\text { inhibition of the baroreceptor reflex, } \\
\text { achieved by occlusion of the carotid } \\
\text { arteries. The circulation is under } \\
\text { neural vasoconstrictor tone, as } \\
\text { evidenced by decreased vascular } \\
\text { resistance in response to section of } \\
\text { the splanchnic nerve. Increased } \\
\text { vascular resistance was observed in } \\
\text { response to SpNS and MNS. }\end{array}$ & $\begin{array}{l}\text { The mesenteric circulation } \\
\text { participated in the baroreceptor reflex } \\
\text { in all age groups. Neural factors } \\
\text { participate in setting basal vascular } \\
\text { tone from birth onwards, but the } \\
\text { decrease in vascular resistance } \\
\text { observed in response to splanchnic } \\
\text { nerve section was greater in older } \\
\text { animals. Vascular resistance } \\
\text { increased to a greater extent in older } \\
\text { animals in response to SpNS. }\end{array}$ \\
\hline 1987 & $\begin{array}{l}\text { Buckley et al. } \\
\text { (67) }\end{array}$ & Swine & 34 & $\begin{array}{l}6 \mathrm{~h}-2 \mathrm{~d} \\
4-7 \mathrm{~d}, 2 \\
\text { wk, } 1,2 \\
\text { mo }\end{array}$ & $\begin{array}{l}\text { Inhibition of the baroreceptor reflex } \\
\text { increased vascular resistance. } \\
\text { Severing the major components of } \\
\text { the innervation increased flow. } \\
\text { Vasoconstriction was observed in } \\
\text { response to mesenteric nerve } \\
\text { stimulation. Autoregulatory escape in } \\
\text { response to sustained MNS was not } \\
\text { observed. }\end{array}$ & $\begin{array}{l}\text { Inhibition of the baroreceptor reflex } \\
\text { increased vascular resistance. } \\
\text { Severing the major components of } \\
\text { the innervation increased flow. } \\
\text { Vasoconstriction was observed in } \\
\text { response to mesenteric nerve } \\
\text { stimulation. Autoregulatory escape in } \\
\text { response to sustained MNS was } \\
\text { observed. }\end{array}$ & $\begin{array}{l}\text { From birth, the mesenteric circulation } \\
\text { is under neural vasoconstrictor tone } \\
\text { and participates in the baroreceptor } \\
\text { reflex. The increase in vascular } \\
\text { resistance was greater and the } \\
\text { latencies for the onset of } \\
\text { vasoconstriction in response to MNS } \\
\text { were smaller in older animals. From } \\
\text { the age of } 2 \text { weeks, autoregulatory } \\
\text { escape during sustained MNS is } \\
\text { demonstrable and it is } \\
\text { well-established by the end of the first } \\
\text { month. }\end{array}$ \\
\hline
\end{tabular}

\section{Extrinsic mechanism}

was observed in response to

achieved by occlusion of the carotid

arteries. The circulation is under

neural vasoconstrictor tone, as

evidenced by decreased vascular

resistance in response to section of

the splanchnic nerve. SpNS

Inhibition of the baroreceptor reflex

.

the innervation increased flow.

Vasoconstriction was observed in

response to mesenteric nerve 
TABLE 2 | Continued

\begin{tabular}{|c|c|c|c|c|c|c|c|}
\hline Year & Author & Species & $n$ & Ages & Newborn & Adolescent/adult & Comparison \\
\hline 1991 & $\begin{array}{l}\text { Nowicki et al. } \\
\text { (68) }\end{array}$ & Swine & 22 & $3,35 d$ & $\begin{array}{l}\text { Vasoconstriction was observed in } \\
\text { response to MNS. Autoregulatory } \\
\text { escape was observed in response to } \\
\text { sustained MNS, however oxygen } \\
\text { uptake remained below baseline. }\end{array}$ & $\begin{array}{l}\text { Vasoconstriction was observed in } \\
\text { response to MNS. Autoregulatory } \\
\text { escape was observed in response to } \\
\text { sustained MNS, however oxygen } \\
\text { uptake remained below baseline. }\end{array}$ & $\begin{array}{l}\text { Sustained MNS produced similar } \\
\text { effects on vascular resistance and } \\
\text { oxygen uptake in newborn and older } \\
\text { animals. Both age groups } \\
\text { demonstrated autoregulatory escape. }\end{array}$ \\
\hline 1996 & $\begin{array}{l}\text { Hoang et al. } \\
\text { (69) }\end{array}$ & Swine & 22 & $\begin{array}{l}0-2 \\
10-14 d\end{array}$ & $\begin{array}{l}\text { Neither } \alpha_{1} \text {-and } \alpha_{2} \text {-adrenoceptors } \\
\text { seem to play a role in the } \\
\text { vasoconstrictor response to } \alpha_{1} \text { - and } \\
\alpha_{2} \text {-agonists, as evidenced by an } \\
\text { unaltered response in the presence of } \\
\alpha_{1} \text { - and } \alpha_{2} \text {-antagonists. }\end{array}$ & $\begin{array}{l}\text { Specific, functional } \alpha_{1} \text { - and } \\
\alpha_{2} \text {-adrenoceptors were present, as } \\
\text { evidenced by blockade of the } \\
\text { vasoconstrtictor response to } \alpha_{1} \text { - and } \\
\alpha_{2} \text {-agonists in the presence of } \alpha_{1} \text { - } \\
\text { and } \alpha_{2} \text {-antagonists, respectively. }\end{array}$ & $\begin{array}{l}\text { Selectivity of } \alpha_{1} \text { - and } \\
\alpha_{2} \text {-adrenoceptor activity was only } \\
\text { observed in older animals. }\end{array}$ \\
\hline 1998 & Nowicki (70) & Swine & 10 & $3,35 d$ & $\begin{array}{l}\text { SP is present. Infusion of SP causes } \\
\text { vasodilation and increases oxygen } \\
\text { uptake. Blockade of SP NK-1 } \\
\text { receptors increases basal vascular } \\
\text { resistance. Blockade of NO } \\
\text { production eliminates SP-induced } \\
\text { vasodilation and increases basal } \\
\text { vascular resistance. }\end{array}$ & $\begin{array}{l}\text { SP is present. Infusion of SP causes } \\
\text { vasodilation and increases oxygen } \\
\text { uptake. Blockade of SP NK-1 } \\
\text { receptors did not alter basal vascular } \\
\text { resistance. Blockade of NO } \\
\text { production eliminates SP-induced } \\
\text { vasodilation. }\end{array}$ & $\begin{array}{l}\text { SP content is greater in newborn } \\
\text { animals. SP participates in setting } \\
\text { basal vascular resistance, but only in } \\
\text { newborn animals. }\end{array}$ \\
\hline 2007 & $\begin{array}{l}\text { Gonzáles- } \\
\text { Luis et al. } \\
(71)\end{array}$ & Swine & 24 & 1,2 wk & $\begin{array}{l}\text { Electrical field stimulation, in the } \\
\text { absence of cholinergic and } \\
\text { adrenergic components, produced } \\
\text { vasodilation, that was eliminated } \\
\text { during blockade of NO production. }\end{array}$ & $\begin{array}{l}\text { Electrical field stimulation, in the } \\
\text { absence of cholinergic and adrenergic } \\
\text { components, produced vasodilation. }\end{array}$ & $\begin{array}{l}\text { Non-adrenergic, non-cholinergic } \\
\text { relaxation was greater in newborn } \\
\text { animals and was eliminated during } \\
\text { blockade of NO production. }\end{array}$ \\
\hline
\end{tabular}

(a-v) $\mathrm{O}_{2}$ : arteriovenous oxygen content difference, d, days, eNOS, endothelial isoform of NO synthase; ET, endothelin; LBW, low birth weight; MNS, mesenteric nerve stimulation; mo, month; NBW, normal birth weight; NO, nitric oxide; $P K C$, protein kinase C; PO2, partial pressure of oxygen; SP, Substance P; SpNS, splanchnic nerve stimulation; wk, week. 
TABLE 3 | Clinical studies in preterm neonates.

\begin{tabular}{|c|c|c|c|c|c|}
\hline Year & Author & Population & $n$ & Measurements & Postnatal changes \\
\hline \multicolumn{6}{|c|}{ Doppler } \\
\hline 1990 & $\begin{array}{l}\text { Van Bel et al. } \\
(16)\end{array}$ & $\begin{array}{l}\text { Preterm and term (GA } \\
24-43 w k)\end{array}$ & 91 & 1-5, daily & $\begin{array}{l}\text { PI increased between } 1 \text { and } 6 \text { days. No significant changes } \\
\text { were observed for PSV, TAMV, and EDV. Values for PSV, } \\
\text { TAMV, and EDV increased with advancing GA. PI was not } \\
\text { associated with GA. In SGA infants, EDV was significantly } \\
\text { higher on day } 1 \text { and PI was significantly lower on days 1-2 } \\
\text { compared to AGA infants. }\end{array}$ \\
\hline 1992 & $\begin{array}{l}\text { Coombs et al. } \\
(72)\end{array}$ & $\begin{array}{l}\text { Preterm (GA 27-35 wk) } \\
\text { and term (GA 37-41 } \\
\text { wk) }\end{array}$ & 18 & $1,2,4 \mathrm{~d}$ & $\begin{array}{l}\text { In term infants, an increase in PSV was observed between } 1 \\
\text { and } 2 \text { days. In preterm infants, no significant changes were } \\
\text { observed in PSV between } 1 \text { and } 4 \text { days. No significant } \\
\text { difference was observed for PSVbetween term and preterm } \\
\text { infants. }\end{array}$ \\
\hline 1996 & $\begin{array}{l}\text { Martinussen } \\
\text { et al. (73) }\end{array}$ & Preterm (GA 33-35 wk) & 15 & 1-7 d, daily & $\begin{array}{l}\text { An increase in TAMV and EDV was observed between } 1 \text { and } \\
2 \text { days. EDV was positive in all infants examined between } 6 \\
\text { and } 24 \mathrm{~h} \text {. No changes were observed after day } 3 \text {. }\end{array}$ \\
\hline 1999 & $\begin{array}{l}\text { Maruyama } \\
\text { et al. (74) }\end{array}$ & Preterm (GA 28-33 wk) & 44 & 1-6 d, daily & $\begin{array}{l}\text { An increase in TAMV was observed between } 1 \text { and } 6 \text { days. A } \\
\text { decrease in RI was observed between } 1 \text { and } 2 \text { days, and } \\
\text { then an increase to } 6 \text { days. A decrease in RVR was observed } \\
\text { between } 1 \text { and } 6 \text { days. }\end{array}$ \\
\hline 1999 & $\begin{array}{l}\text { Yanowitz } \\
\text { et al. (75) }\end{array}$ & $\begin{array}{l}\text { VLBW (BW } \\
750-1,250 \mathrm{~g})\end{array}$ & 20 & $\begin{array}{l}6,30,54 \mathrm{~h}, 7, \text { and } \\
14 \mathrm{~d}\end{array}$ & $\begin{array}{l}\text { An increase in TAMV was observed between } 6 \mathrm{~h} \text { and } 7 \text { days } \\
\text { and between } 6 \mathrm{~h} \text { and } 14 \text { days. No significant changes were } \\
\text { observed in EDV and RVR. }\end{array}$ \\
\hline 2001 & $\begin{array}{l}\text { Maruyama } \\
\text { et al. (76) }\end{array}$ & $\begin{array}{l}\text { VLBW, SGA (BW } \\
<1,500 \mathrm{~g} \text { and below } \\
\text { the } 10 \text { th percentile }\end{array}$ & 10 & 1-7 d, daily & $\begin{array}{l}\text { An increase in PSV was observed between } 1 \text { and } 6-7 \text { days. } \\
\text { An increase in TAMV was observed between } 1 \text { and 5-6 days. } \\
\text { An increase in EDV was observed between } 1 \text { and 3-7 days. A } \\
\text { decrease in RI was observed between } 1 \text { and } 2-7 \text { days. A } \\
\text { decrease in RVR was observed between 1-6 days. PSV, } \\
\text { TAMV, and EDV were lower in SGA infants compared to AGA } \\
\text { infants. }\end{array}$ \\
\hline 2006 & $\begin{array}{l}\text { Havranek } \\
\text { et al. (77) }\end{array}$ & Preterm (GA <34 wk) & 25 & $1-5 \mathrm{~d}$, daily & $\begin{array}{l}\text { An increase in PSV and TAMV was observed between } 1 \text { and } \\
5 \text { days. }\end{array}$ \\
\hline 2009 & $\begin{array}{l}\text { Papacci et al. } \\
(78)\end{array}$ & $\begin{array}{l}\text { Preterm (GA 25-28 wk, } \\
\text { 29-32 wk, 33-36 wk) } \\
\text { and term (GA 37-41 } \\
\text { wk) }\end{array}$ & 69 & $\begin{array}{l}1,3,7,14,21 \\
\text { and } 28 \mathrm{~d}\end{array}$ & $\begin{array}{l}\text { An increase in PSV, EDV and TAMV was observed between } 1 \\
\text { and } 28 \text { days. Values for PSV, EDV, and TAMV increased with } \\
\text { advancing GA. No changes in PI an RI were observed. }\end{array}$ \\
\hline 2012 & $\begin{array}{l}\text { Havranek } \\
\text { et al. (79) }\end{array}$ & VLBW (BW <1,500 g) & 35 & $\begin{array}{l}1,3,5,7,10, \text { and } \\
14 \mathrm{~d}\end{array}$ & $\begin{array}{l}\text { An increase in PSV and TAMV was observed between } 1 \text { and } \\
14 \text { days. Lower values on day } 1 \text { were associated with higher } \\
\text { post-natal increases in PSV and TAMV. No change in EDV } \\
\text { was observed. No correlation was found between GA and } \\
\text { day } 1 \text { PSV and TAMV. }\end{array}$ \\
\hline 2014 & $\begin{array}{l}\text { Thompson } \\
\text { et al. (80) }\end{array}$ & $\begin{array}{l}\text { Preterm (GA }<27 \text { wk, } \\
27-31 w k \text {, and } 31-36 \\
\text { wk) }\end{array}$ & 41 & $\begin{array}{l}1,1-4,5-7,8-14 \\
\text { and } 15-28\end{array}$ & $\begin{array}{l}\text { No differences were observed in PSV on day } 1 \text { between GA } \\
\text { groups. However, on day } 5-7 \text { and 8-14 higher GA was } \\
\text { associated with higher PSV. }\end{array}$ \\
\hline 2015 & $\begin{array}{l}\text { Gursoy et al. } \\
(81)\end{array}$ & Preterm (GA 26-34 wk) & 25 & 1-5 d, daily & $\begin{array}{l}\text { An increase in PSV, TAMV and EDV was observed between } 1 \\
\text { and } 5 \text { days. A decrease in RI was observed between } 1 \text { and } 5 \\
\text { days. }\end{array}$ \\
\hline 2018 & $\begin{array}{l}\text { Kocvarova } \\
\text { et al. (82) }\end{array}$ & $\begin{array}{l}\text { Preterm (GA 34-37 wk) } \\
\text { and term (GA 38-42 } \\
\text { wk) }\end{array}$ & 40 & 2,24, and $72 \mathrm{~h}$ & $\begin{array}{l}\text { An increase in PSV was observed between } 2 \text { and } 72 \mathrm{~h} \text {. An } \\
\text { increase in EDV was observed between } 2 \text { and } 24 \mathrm{~h} \text {. All EDV } \\
\text { values were positive at } 24 \mathrm{~h} \text {. An increase in TAMV was } \\
\text { observed between } 2 \text { and } 24 \mathrm{~h} \text { and between } 24 \text { and } 72 \mathrm{~h} \text {. A } \\
\text { decrease in PI and RI was observed between } 2 \text { and } 24 \mathrm{~h} \text {. } \\
\text { Preterm infants had lower Pl at } 2 \mathrm{~h} \text { and higher PSV and EDV } \\
\text { at } 24 \mathrm{~h} \text { compared to term infants. }\end{array}$ \\
\hline
\end{tabular}


TABLE 3 | Continued

\begin{tabular}{|c|c|c|c|c|c|}
\hline Year & Author & Population & $n$ & Measurements & Postnatal changes \\
\hline \multicolumn{6}{|c|}{ NIRS } \\
\hline 2010 & $\begin{array}{l}\text { Cortez et al. } \\
\text { (83) }\end{array}$ & Preterm (GA $\leq 30$ wk) & 19 & $\begin{array}{l}48 \mathrm{~h}-14 \mathrm{~d} \\
\text { continuously }\end{array}$ & $\begin{array}{l}\text { A decrease in daily mean } \mathrm{r}_{\mathrm{s}} \mathrm{SO}_{2} \text { was observed between } 48 \mathrm{~h} \\
\text { until } 9 \text { days, and then an increase between } 10 \text { and } 14 \text { days. }\end{array}$ \\
\hline 2011 & $\begin{array}{l}\text { McNeill et al. } \\
\text { (84) }\end{array}$ & $\begin{array}{l}\text { Preterm (GA 29-30 wk } \\
\text { and 32-33 wk) }\end{array}$ & 12 & $\begin{array}{l}0-21 \text { days, } \\
\text { continuously }\end{array}$ & $\begin{array}{l}\text { A decrease in daily mean } \mathrm{r}_{\mathrm{s}} \mathrm{SO}_{2} \text { was observed between } 1 \\
\text { and } 7 \text { days in infants with } \mathrm{GA} 29-30 \text { wk and between } 1 \text { and } \\
4.5 \text { days in infants with } \mathrm{GA} 32-33 \text { wk. Afterwards, an } \\
\text { increase in } \mathrm{r}_{\mathrm{s}} \mathrm{SO}_{2} \text { was observed. Lower GA was associated } \\
\text { with lower } \mathrm{r}_{\mathrm{s}} \mathrm{SO}_{2} \text { values. }\end{array}$ \\
\hline 2014 & $\begin{array}{l}\text { Patel et al. } \\
\text { (85) }\end{array}$ & $\begin{array}{l}\text { Preterm (GA }<32 \text { wk } \\
\text { and birth weight } \\
<1,500 \mathrm{~g})\end{array}$ & 92 & $0-7$ d, 5 min daily & $\begin{array}{l}\text { An increase in mean } r_{s} \mathrm{SO}_{2} \text { was observed between } 1 \text { and } 3 \\
\text { days. Afterwards, a decrease in } r_{s} \mathrm{SO}_{2} \text { was observed. }\end{array}$ \\
\hline 2016 & $\begin{array}{l}\text { Bozzetti et al. } \\
(86)\end{array}$ & Preterm (GA 29-33 wk) & 20 & $\begin{array}{l}0-24,48-72,3 \mathrm{~h} \\
\text { daily }\end{array}$ & $\begin{array}{l}\text { A decrease in } \mathrm{r}_{\mathrm{s}} \mathrm{SO}_{2} \text { was observed between } 0-24 \mathrm{~h} \text { and } \\
48-72 \mathrm{~h} \text {. In IUGR infants } \mathrm{r}_{\mathrm{s}} \mathrm{SO}_{2} \text { was significantly lower } \\
\text { compared to non-IUGR infants. }\end{array}$ \\
\hline 2019 & Kuik et al. (88) & $\begin{array}{l}\text { Preterm }(\mathrm{GA}<30 \mathrm{wk} \\
\text { or birth weight } \\
<1,000 \mathrm{~g}, \text { or } \mathrm{GA}<32 \\
\text { wk and birth weight } \\
<1,200 \mathrm{~g}\end{array}$ & 29 & $\begin{array}{l}2-5,8,15,22,29 \\
36 \text { d, } 2 \text { h on each } \\
\text { day }\end{array}$ & $\begin{array}{l}\text { Generally, an increase in } \mathrm{r}_{\mathrm{s}} \mathrm{SO}_{2} \text { was observed between } 2 \text { and } \\
36 \text { days, with the lowest values on day } 4 \text { and day } 15 \text {. }\end{array}$ \\
\hline
\end{tabular}

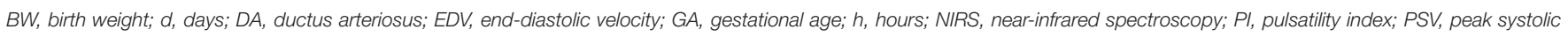
velocity; $\mathrm{Rl}$, resistance index; $r_{S} \mathrm{SO}_{2}$, splanchnic oxygen saturation; RVR, relative vascular resistance; TAMV, time-averaged mean velocity; VLBW, very low birth weight; wh, weeks.

and has not been fully elucidated, but may include impaired intestinal microcirculation (14). In preterm neonates, loss of NO production may thus predispose the intestine to hypoxic tissue injury, possibly contributing to the development of NEC.

We acknowledge some limitations. First, our review describes the mechanistic strategies available to neonatal and mature intestine to maintain adequate oxygenation, but does not include the contribution of these strategies during external influences that may alter intestinal oxygen supply or demand, e.g., anemia and enteral feeding. Nevertheless, our speculations on implications of these external influences on intestinal oxygenation are supported by recent reviews in both animal models and preterm neonates $(18,19,44)$. Second, we purposely did not take into account factors that may influence the maturation processes described. These factors may include structural maturation and growth of intestinal tissue and vascularization networks, microbial colonization, and increasing volumes of enteral feeding (6, 90-92). Third, inherent limitations in Doppler and NIRS techniques complicate the translation to clinical implications. Doppler requires trained personnel, is prone to operator-dependent bias and provides only momentary blood flow velocity measurements of large vessels, whereas NIRS is challenged by intraindividual variability and interference of other tissues, intestinal contents and bowel movements with splanchnic oxygen saturation measurements (18). Finally, translation of our findings, derived from animal studies, to implications for preterm neonates is complicated by interspecies differences. By using NIRS to more regularly monitor $\mathrm{r}_{\mathrm{S}} \mathrm{SO}_{2}$ in preterm neonates, we may be able to learn more about the maturational phenomena described previously. For instance, it may provide insight in the influence of GA and post-natal age on basal intestinal oxygenation and it may be used to study the response to external influences that alter oxygen supply or oxygen demand. At the same time, a better understanding of post-natal maturation of intestinal oxygenation mechanisms may facilitate interpretation of $\mathrm{r}_{\mathrm{S}} \mathrm{SO}_{2}$ and advance the use of NIRS in a clinical setting. Ultimately, bedside $\mathrm{r}_{5} \mathrm{SO}_{2}$-monitoring may lead to more streamlined and personalized care practices for at-risk neonates.

In conclusion, preterm intestine may have a smaller reserve for perturbations in intestinal oxygen delivery and oxygen demand, as oxygen extraction may be already be maximized under baseline circumstances. Developing additional understanding on this delicate balance of oxygen supply and demand may help in guiding clinical management to prevent intestinal tissue hypoxia.

\section{AUTHOR CONTRIBUTIONS}

$\mathrm{BD}$ and EK conceptualized and designed the study. BD screened databases for eligible studies, drafted the initial manuscript, and revised the manuscript after feedback from coauthors. JMi, $\mathrm{JMo}, \mathrm{JH}, \mathrm{AB}$, and EK critically reviewed the article. All authors contributed to the article and approved the submitted version.

\section{FUNDING}

This research project was part of the research program of the Research Institute of Behavioral and Cognitive Neurosciences, Graduate School of Medical Sciences, University of Groningen, participation in which is financially supported by the Junior Scientific Master Class of the University of Groningen. 


\section{REFERENCES}

1. Greenwood-Van Meerveld B, Johnson AC, Grundy D. Gastrointestinal physiology and function. In: Greenwood-Van Meerveld B, editor. Gastrointestinal Pharmacology Handbook of Experimental Pharmacology. Vol. 239. Cham: Springer (2017). p. 1-16. doi: 10.1007/164_2016_118

2. Volk N, Lacy B. Anatomy and physiology of the small bowel. Gastrointest Endosc Clin N Am. (2017) 27:1-13. doi: 10.1016/j.giec.2016.08.001

3. Santaolalla R, Abreu MT. Innate immunity in the small intestine. Curr Opin Gastroenterol. (2012) 28:124-9. doi: 10.1097/MOG.0b013e3283506559

4. Buettner M, Lochner M. Development and function of secondary and tertiary lymphoid organs in the small intestine and the colon. Front Immunol. (2016) 7:342. doi: 10.3389/fimmu.2016.00342

5. Lister G, Walter TK, Versmold HT, Dallman PR, Rudolph AM. Oxygen delivery in lambs: cardiovascular and hematologic development. Am J Physiol. (1979) 237:H668-75. doi: 10.1152/ajpheart.1979.237.6.H668

6. Edelstone DI, Holzman IR. Oxygen consumption by the gastrointestinal tract and liver in conscious newborn lambs. Am J Physiol. (1981) 240:G297304. doi: 10.1152/ajpgi.1981.240.4.G297

7. Morgan JA, Young L, McCormick FM, McGuire W. Promoting growth for preterm infants following hospital discharge. Arch Dis Child Fetal Neonatal Ed. (2012) 97:295-8. doi: 10.1136/adc.2009.170910

8. Matheson PJ, Wilson MA, Garrison RN. Regulation of intestinal blood flow. $J$ Surg Res. (2000) 93:182-96. doi: 10.1006/jsre.2000.5862

9. Reber KM, Nankervis CA, Nowicki PT. Newborn intestinal circulation. Physiology and pathophysiology. Clin Perinatol. (2002) 29:23-39. doi: 10.1016/S0095-5108(03)00063-0

10. Widdowson EM. Development of the digestive system: Comparative animal studies. Am J Clin Nutr. (1985) 41(Suppl. 2):38490. doi: 10.1093/ajcn/41.2.384

11. Dasgupta S, Arya S, Choudhary S, Jain SK. Amniotic fluid: source of trophic factors for the developing intestine. World J Gastrointest Pathophysiol. (2016) 7:38-47. doi: 10.4291/wjgp.v7.i1.38

12. Rhee CJ, Fraser CD, Kibler K, Easley RB, Andropoulos DB, Czosnyka M, et al. The ontogeny of cerebrovascular pressure autoregulation in premature infants. J Perinatol. (2014) 34:926-31. doi: 10.1038/jp.2014.122

13. Nowicki PT. Ischemia and necrotizing enterocolitis: where, when, and how. Semin Pediatr Surg. (2005) 14:152-8. doi: 10.1053/j.sempedsurg.2005.05.003

14. Niño DF, Sodhi CP, Hackam DJ. Necrotizing enterocolitis: new insights into pathogenesis and mechanisms. Nat Rev Gastroenterol Hepatol. (2016) 13:590-600. doi: 10.1038/nrgastro.2016.119

15. Clark RH, Thomas P, Peabody J. Extrauterine growth restriction remains a serious problem in prematurely born neonates. Pediatrics. (2003) $111(5 \mathrm{Pt}$ 1):986-90. doi: 10.1542/peds.111.5.986

16. Van Bel F, Van Zwieten PH, Guit GL, Schipper J. Superior mesenteric artery blood flow velocity and estimated volume flow: duplex doppler US study of preterm and term neonates. Radiology. (1990) 174:1659. doi: 10.1148/radiology.174.1.2403678

17. Mintzer JP, Moore JE. Regional tissue oxygenation monitoring in the neonatal intensive care unit: evidence for clinical strategies and future directions. Pediatr Res. (2019) 86:296-304. doi: 10.1038/s41390-019-0466-9

18. Martini S, Corvaglia L. Splanchnic NIRS monitoring in neonatal care: rationale, current applications and future perspectives. J Perinatol. (2018) 38:431-43. doi: 10.1038/s41372-018-0075-1

19. Seager E, Longley C, Aladangady N, Banerjee J. Measurement of gut oxygenation in the neonatal population using near-infrared spectroscopy: a clinical tool? Arch Dis Child Fetal Neonatal Ed. (2020) 105:7686. doi: 10.1136/archdischild-2018-316750

20. Granger HJ, Nyhof RA. Dynamics of intestinal oxygenation: interactions between oxygen supply and uptake. Am J Physiol. (1982) 243:G916. doi: 10.1152/ajpgi.1982.243.2.G91

21. Shepherd AP. Local control of intestinal oxygenation and blood flow. Annu Rev Physiol. (1982) 44:13-27. doi: 10.1146/annurev.ph.44.030182. 000305

22. Mortillaro NA. Microcirculation of the small intestine. In: Mortillaro NA, editor. The Physiology and Pharmacology of the Microcirculation. Vol. 2. Orlando, FL: Academic Press (1984). p. 57-72. doi: 10.1016/B978-0-12-508302-7.50011-4
23. Granger DN, Richardson PD, Kvietys PR, Mortillaro NA. Intestinal blood flow. Gastroenterology. (1980) 78:837-63. doi: 10.1016/0016-5085(80)90692-7

24. Stark ME, Szurszewski JH. Role of nitric oxide in gastrointestinal and hepatic function and disease. Gastroenterology. (1992) 103:192849. doi: 10.1016/0016-5085(92)91454-C

25. Shepherd AP, Riedel GL. Effect of pulsatile pressure and metabolic rate on intestinal autoregulation. Am J Physiol. (1982) 242:H769-75. doi: 10.1152/ajpheart.1982.242.5.H769

26. Pohl U, Herlan K, Huang A, Bassenge E. EDRF-mediated shear-induced dilation opposes myogenic vasoconstriction in small rabbit arteries. Am J Physiol. (1991) 261(6 Pt 2):H2016-23. doi: 10.1152/ajpheart.1991.261.6.H2016

27. Bayliss WM. On the local reactions of the arterial wall to changes of internal pressure. J Physiol. (1902) 28:220-31. doi: 10.1113/jphysiol.1902.sp000911

28. Shepherd AP. Myogenic responses of intestinal resistance and exchange vessels. Am J Physiol. (1977) 233:H54754. doi: 10.1152/ajpheart.1977.233.5.H547

29. Meininger GA, Davis MJ. Cellular mechanisms involved in the vascular myogenic response. Am J Physiol. (1992) $263(3 \mathrm{Pt}$ 2):H647-59. doi: 10.1152/ajpheart.1992.263.3.H647

30. Ringvold HC, Khalil RA. Protein kinase $\mathrm{C}$ as regulator of vascular smooth muscle function and potential target in vascular disorders. Adv Pharmacol. (2017) 78:203-301. doi: 10.1016/bs.apha.2016.06.002

31. Granger HJ, Norris CP. Intrinsic regulation of intestinal oxygenation in the anesthetized dog. Am J Physiol. (1980) 238:836-43. doi: 10.1152/ajpheart.1980.238.6.H836

32. Ignarro LJ, Buga GM, Wood KS, Byrns RE, Chaudhurit G. Endothelium-derived relaxing factor produced and released from artery and vein is nitric oxide. Proc Natl Acad Sci USA. (1987) 84:9265-9. doi: 10.1073/pnas.84.24.9265

33. Palmer RM, Ferrige AG, Moncada S. Nitric oxide release accounts for the biological activity of endothelium-derived relaxing ractor. Nature. (1987) 327:524-6. doi: 10.1038/327524a0

34. Palmer RM, Rees DD, Ashton DS, Moncada S. L-arginine is the physiological precursor for the formation of nitric oxide in endotheliumdependent relaxation. Biochem Biophys Res Commun. (1988) 153:12516. doi: $10.1016 /$ S0006-291X(88)81362-7

35. Masaki T. Possible role of endothelin in endothelial regulation of vascular tone. Annu Rev Pharmacol Toxicol. (1995) 35:23555. doi: 10.1146/annurev.pa.35.040195.001315

36. Surprenant A. Control of the gastrointestinal tract by enteric neurons. Annu Rev Physiol. (1994) 56:117-40. doi: 10.1146/annurev.ph.56.030194.001001

37. Greenway C V, Scott GD, Zink J. Sites of autoregulatory escape of blood flow in the mesenteric vascular bed. J Physiol. (1976) 259:112. doi: 10.1113/jphysiol.1976.sp011451

38. Folkow B, Lewis DH, Lundgren O, Mellander S, Wallentin I. The effect of graded vasoconstrictor fibre stimulation on the intestinal resistance and capacitance vessels. Acta Physiol Scand. (1964) 61:445-57.

39. Remak G, Hottenstein OD, Jacobson ED. Sensory nerves mediate neurogenic escape in rat gut. Am J Physiol. (1990) $258(3 \mathrm{Pt}$ 2):778-86. doi: 10.1152/ajpheart.1990.258.3.H778

40. Buckley NM. Maturation of circulatory system in three mammalian models of human development. Comp Biochem Physiol A Comp Physiol. (1986) 83:1-7. doi: 10.1016/0300-9629(86)90080-0

41. Crissinger KD. Regulation of hemodynamics and oxygenation in developing intestine: insight into the pathogenesis of necrotizing enterocolitis. Acta Paediatr Suppl. (1994) 396:8-10. doi: 10.1111/j.1651-2227.1994.tb13233.x

42. Nankervis CA, Reber KM, Nowicki PT. Age-dependent changes in the postnatal intestinal microcirculation. Microcirculation. (2001) 8:37787. doi: 10.1111/j.1549-8719.2001.tb00185.x

43. Boegehold MA. Endothelium-dependent control of vascular tone during early postnatal and juvenile growth. Microcirculation. (2010) 17:394406. doi: 10.1111/j.1549-8719.2010.00035.x

44. Chaaban H, Stonestreet BS. Intestinal hemodynamics and oxygenation in the perinatal period. Semin Perinatol. (2012) 36:260-8. doi: 10.1053/j.semperi.2012.04.006

45. Crissinger KD, Kvietys PR, Granger DN. Developmental intestinal vascular responses to venous pressure elevation. Am J Physiol. (1988) 254:G65863. doi: 10.1152/ajpgi.1988.254.5.G658 
46. Nowicki PT, Miller CE. Autoregulation in the developing postnatal intestinal circulation. Am J Physiol. (1988) $254(2 \mathrm{Pt}$ 1):G189-93. doi: 10.1152/ajpgi.1988.254.2.G189

47. Nowicki PT, Miller CE. Effect of $\mathrm{O} 2$ availability on intrinsic vascular response to venous pressure elevation in postnatal swine intestine. Am J Physiol. (1990) 258:G873-7. doi: 10.1152/ajpgi.1990.258.6.G873

48. Nowicki PT, Miller CE, Edwards RC. Effects of hypoxia and ischemia on autoregulation in postnatal intestine. Am J Physiol. (1991) 261(1 Pt 1):G1527. doi: 10.1152/ajpgi.1991.261.1.G152

49. Nowicki PT, Miller CE. Effect of increased tissue oxygen uptake on autoregulation in postnatal intestine. Am J Physiol. (1992) 263:G6904. doi: 10.1152/ajpgi.1992.263.5.G690

50. Nowicki PT, Miller CE. Regulation of capillary exchange capacity in postnatal swine intestine. Am J Physiol. (1993) 265:G10907. doi: 10.1152/ajpgi.1993.265.6.G1090

51. Nankervis CA, Nowicki PT. Role of nitric oxide in regulation of vascular resistance in postnatal intestine. Am J Physiol. (1995) 268:G94958. doi: 10.1152/ajpgi.1995.268.6.G949

52. Nakanishi T, Gu H, Abe K, Momma K. Developmental changes in the contractile system of the mesenteric small artery of rabbit. Pediatr Res. (1997) 41:65-71. doi: 10.1203/00006450-199701000-00010

53. Nowicki PT. Effects of sustained flow reduction on postnatal intestinal circulation. Am J Physiol. (1998) 275:G75868. doi: 10.1152/ajpgi.1998.275.4.G758

54. Reber KM, Nowicki PT. Pressure and flow characteristics of terminal mesenteric arteries in postnatal intestine. Am J Physiol. (1998) 274:G2908. doi: 10.1152/ajpgi.1998.274.2.G290

55. Nowicki PT. Effects of sustained low-flow perfusion on the response to vasoconstrictor agents in postnatal intestine. Am J Physiol. (1999) 276:G140816. doi: 10.1152/ajpgi.1999.276.6.G1408

56. Nankervis CA, Nowicki PT. Role of endothelin-1 in regulation of the postnatal intestinal circulation. Am J Physiol Gastrointest Liver Physiol. (2000) 278:36775. doi: 10.1152 /ajpgi.2000.278.3.G367

57. Nankervis CA, Schauer GM, Miller CE. Endothelin-mediated vasoconstriction in postischemic newborn intestine. Am J Physiol Gastrointest Liver Physiol. (2000) 279:683-91. doi: 10.1152/ajpgi.2000.279.4.G683

58. Nankervis CA, Dunaway DJ, Nowicki PT. Determinants of terminal mesenteric artery resistance during the first postnatal month. Am J Physiol Gastrointest Liver Physiol. (2001) 280:G67886. doi: 10.1152/ajpgi.2001.280.4.G678

59. Nankervis CA, Dunaway DJ, Miller CE. Endothelin ET(A) and ET(B) receptors in postnatal intestine. Am J Physiol Gastrointest Liver Physiol. (2001) 280:555-62. doi: 10.1152/ajpgi.2001.280.4.G555

60. Reber KM, Mager GM, Miller CE, Nowicki PT. Relationship between flow rate and NO production in postnatal mesenteric arteries. Am J Physiol Gastrointest Liver Physiol. (2001) 280:G43-50. doi: 10.1152/ajpgi.2001.280.1.G43

61. Reber KM, Su BY, Reed Clark K, Pohlman DL, Miller CE, Nowicki PT. Developmental expression of eNOS in postnatal swine mesenteric artery. Am J Physiol Gastrointest Liver Physiol. (2002) 283:G132835. doi: 10.1152/ajpgi.00067.2002

62. Su BY, Reber KM, Nankervis CA, Nowicki PT. Development of the myogenic response in postnatal intestine: role of PKC. Am J Physiol Gastrointest Liver Physiol. (2003) 284:G445-52. doi: 10.1152/ajpgi.00259.2002

63. Su BY, Reber KM, Nankervis CA. Developmental expression of endothelin receptors in postnatal swine mesenteric artery. Pediatr Res. (2004) 56:35965. doi: 10.1203/01.PDR.0000134253.86014.B9

64. Wendel M, Kummer W, Knels L, Schmeck J, Koch T. Muscular ETB receptors develop postnatally and are differentially distributed in specific segments of the rat vasculature. J Histochem Cytochem. (2005) 53:18796. doi: 10.1369/jhc.4A6474.2005

65. Ayuso M, Van Cruchten S, Van Ginneken C. Birthweight determines intestinal microvasculature development and alters endothelial nitric oxide synthase density in young piglets. Anat Histol Embryol. (2020) 00:18. doi: 10.1111/ahe.12534

66. Buckley NM, Brazeau P, Frasier ID, Gootman PM. Circulatory effects of splanchnic nerve stimulation in developing swine. Am J Physiol. (1985) 248(1 Pt 2):H69-74. doi: 10.1152/ajpheart.1985.248.1.H69
67. Buckley NM, Jarenwattananon M, Gootman PM, Frasier ID. Autoregulatory escape from vasoconstriction of intestinal circulation in developing swine. Am J Physiol. (1987) 252:H118-24. doi: 10.1152/ajpheart.1987.252.1.H118

68. Nowicki PT, Miller CE, Hayes JR. Effect of sustained mesenteric nerve stimulation on intestinal oxygenation in developing swine. Am J Physiol. (1991) 260(2 Pt 1):G333-9. doi: 10.1152/ajpgi.1991.260.2.G333

69. Hoang T V, Choe EU, Lippton HL, Hyman AL, Flint LM, Ferrara JJ. Effect of maturation on alpha-adrenoceptor activity in newborn piglet mesentery. $J$ Surg Res. (1996) 61:330-8. doi: 10.1006/jsre.1996.0125

70. Nowicki PT. Postnatal changes in gut hemodynamics: a possible role for substance P. Am J Physiol. (1998) 274:G114250. doi: 10.1152/ajpgi.1998.274.6.G1142

71. González-Luis G, Fletcher AJW, Moreno L, Pérez-Vizcaíno F, Blanco CE, Villamor E. Nitric oxide-mediated nonadrenergic noncholinergic relaxation of piglet pulmonary arteries decreases with postnatal age. J Physiol Pharmacol. (2007) 58:45-56.

72. Coombs RC, Morgan ME, Durbin GM, Booth IW, McNeish AS. Abnormal gut blood flow velocities in neonates at risk of necrotising enterocolitis. J Pediatr Gastroenterol Nutr. (1992) 15:13-9. doi: 10.1097/00005176-199207000-00003

73. Martinussen M, Brubakk AM, Vik T, Yao AC. Mesenteric blood flow velocity and its relation to transitional circulatory adaptation in appropriate for gestational age preterm infants. Pediatr Res. (1996) 39:275-80. doi: 10.1203/00006450-199602000-00015

74. Maruyama K, Koizumi T, Tomomasa T, Morikawa A. Intestinal blood-flow veolicty in umcomplicated preterm infants during the early neonatal period. Pediatr Radiol. (1999) 29:472-7. doi: 10.1007/s002470050621

75. Yanowitz TD, Yao AC, Pettigrew KD, Werner JC, Stonestreet BS. Postnatal hemodynamic changes in very-low-birthweight infants. J Appl Physiol. (1999) 87:370-80. doi: 10.1152/jappl.1999.87.1.370

76. Maruyama K, Koizumi T. Superior mesenteric artery blood flow velocity in small for gestational age infants of very low birth weight during the early neonatal period. J Perinat Med. (2001) 29:64-70. doi: 10.1515/JPM.2001.009

77. Havranek T, Thompson Z, Carver JD. Factors that influence mesenteric artery blood flow velocity in newborn preterm infants. J Perinatol. (2006) 26:493-7. doi: 10.1038/sj.jp.7211551

78. Papacci P, Giannantonio C, Cota F, Latella C, Semeraro CM, Fioretti M, et al. Neonatal colour Doppler ultrasound study: Normal values of abdominal blood flow velocities in the neonate during the first month of life. Pediatr Radiol. (2009) 39:328-35. doi: 10.1007/s00247-008-1112-6

79. Havranek T, Miladinovic B, Wadhawan R, Carver JD. Factors that affect the postnatal increase in superior mesenteric artery blood flow velocity in very low birth weight preterm infants. J Perinat Med. (2012) 40:56570. doi: 10.1515/jpm-2011-0235

80. Thompson A, Silva CT, Gork AS, Wang D, Ehrenkranz RA. Intestinal blood flow by doppler ultrasound: the impact of gestational age and time from first enteral feeding in preterm neonates. Am J Perinatol. (2014) 31:2618. doi: $10.1055 / \mathrm{s}-0033-1347365$

81. Gursoy T, Imamoglu EY, Ovali F, Karatekin G. Effects of antenatal magnesium exposure on intestinal blood flow and outcome in preterm neonates. Am J Perinatol. (2015) 32:1064-9. doi: 10.1055/s-0035-1548541

82. Kocvarova L, Mackovicova L, Matasova K, Zibolen M. The early postnatal blood flow characteristics in the superior mesenteric and coeliac arteries in late preterm neonates. J Matern Fetal Neonatal Med. (2018) 31:302732. doi: $10.1080 / 14767058.2017 .1362553$

83. Cortez J, Gupta M, Amaram A, Pizzino J, Sawhney M, Sood BG. Noninvasive evaluation of splanchnic tissue oxygenation using near-infrared spectroscopy in preterm neonates. J Matern Fetal Neonatal Med. (2011) 24:574-82. doi: 10.3109/14767058.2010.511335

84. McNeill S, Gatenby JC, McElroy S, Engelhardt B. Normal cerebral, renal and abdominal regional oxygen saturations using near-infrared spectroscopy in preterm infants. J Perinatol. (2011) 31:51-7. doi: 10.1038/jp.2010.71

85. Patel AK, Lazar DA, Burrin DG, O’Brian Smith E, Magliaro TJ, Stark AR, et al. Abdominal near-infrared spectroscopy measurements are lower in preterm infants at risk for necrotizing enterocolitis. Pediatr Clin Care Med. (2014) 15:735-41. doi: 10.1097/PCC.0000000000000211

86. Bozzetti V, Paterlini G, Van Bel F, Visser GHA, Tosetti L, Gazzolo D, et al. Cerebral and somatic NIRS-determined oxygenation in IUGR preterm 
infants during transition. J Matern Fetal Neonatal Med. (2016) 29:4436. doi: 10.3109/14767058.2014.1003539

87. Ledo A, Aguar M, Núñez-Ramiro A, Saénz P, Vento M. Abdominal nearinfrared spectroscopy detects low mesenteric perfusion early in preterm infants with hemodynamic significant ductus arteriosus. Neonatology. (2017) 112:238-45. doi: 10.1159/000475933

88. Kuik SJ, Van Zoonen AGJF, Bos AF, Van Braeckel KNJA, Hulscher JBF, Kooi EMW. The effect of enteral bolus feeding on regional intestinal oxygen saturation in preterm infants is age-dependent: a longitudinal observational study. BMC Pediatr. (2019) 19:404. doi: 10.1186/s12887-0191805-z

89. Nowicki PT, Caniano DA, Hammond S, Giannone PJ, Besner GE, Reber KM, et al. Endothelial nitric oxide synthase in human intestine resected for necrotizing enterocolitis. J Pediatr. (2007) 150:40-5. doi: 10.1016/j.jpeds.2006.09.029

90. Castillo RO, Pittler A, Costa F. Intestinal maturation in the rat: The role of enteral nutrients. J Parenter Enter Nutr. (1988) 12:4905. doi: $10.1177 / 0148607188012005490$
91. Hooper L V, Wong MH, Thelin A, Hansson L, Falk PG, Gorden JI. Molecular analysis of commensal host-microbial relationships in the intestine. Science. (2001) 291:881-4. doi: 10.1126/science.291.5505.881

92. Chen YM, Zhang JS, Duan XL. Changes of microvascular architecture, ultrastructure and permeability of rat jejunal villi at different ages. World $J$ Gastroenterol. (2003) 9:795-9. doi: 10.3748/wjg.v9.i4.795

Conflict of Interest: The authors declare that the research was conducted in the absence of any commercial or financial relationships that could be construed as a potential conflict of interest.

Copyright (๑ 2020 Dotinga, Mintzer, Moore, Hulscher, Bos and Kooi. This is an open-access article distributed under the terms of the Creative Commons Attribution License (CC BY). The use, distribution or reproduction in other forums is permitted, provided the original author(s) and the copyright owner(s) are credited and that the original publication in this journal is cited, in accordance with accepted academic practice. No use, distribution or reproduction is permitted which does not comply with these terms. 